\title{
Why Wadi Al Bih Limestone is the Most Sustainable Aquifer in the United Arab Emirates?
}

\author{
Zeinelabidin E. RIZK* \\ Institute of Environment, Water and Energy, Ajman University of Science and Technology, Ajman, UAE
}

\begin{abstract}
Results of several research studies conducted on Wadi Al Bih Basin in Ras Al Khaimah area between 1996 and 2015 were used to answer the question: why Wadi Al Bih limestone is the most sustainable aquifer in the United Arab Emirates (UAE)?

Extensive field work, climatic data, hydrogeologic studies, results of chemical analysis of 193 groundwater samples, records of stable $\left({ }^{2} \mathrm{H}\right.$ and $\left.{ }^{18} \mathrm{O}\right)$ and radioisotopes $\left({ }^{3} \mathrm{H}\right.$ and $\left.{ }^{14} \mathrm{C}\right)$ in 52 rainwater samples and 312 groundwater samples, analysis of aquifer recharge to discharge and findings of a numerical model were used in this investigation.

Results show that Wadi Al Bih basin receives an average annual rainfall of $155 \mathrm{~mm}$, which is higher the UAE annual average (119 $\mathrm{mm})$. Annual rainfall in excess of $400 \mathrm{~mm}$ is common in the study area. The percentage of aquifer recharge from the total annual rainfall $\left(74\right.$ million $\left.\mathrm{m}^{3}\right)$ was $\approx 9 \%\left(6.7\right.$ million $\left.\mathrm{m}^{3}\right)$, increased to $13 \%\left(17.6\right.$ million $\left.\mathrm{m}^{3}\right)$ after construction of Wadi $\mathrm{Al}$ Bih dam in 1982. In the meantime, the reduction of average annual groundwater production from Wadi Al Bih limestone aquifer decreased from 9 million $\mathrm{m}^{3}$ during the period 1991-1995 to 4.5 million $\mathrm{m}^{3}$ during the period 2010-2014. The decrease in groundwater pumping from the aquifer paralleled the construction of Al Burayrat, Al Humraniah, Rafaq, Ghalilah and Al Nakheel desalination plants, with a total production capacity of 93 thousand $\mathrm{m}^{3}$ per day. These conditions has eased pressure on aquifer, increased groundwater storage, raised of hydraulic heads by $1 \mathrm{~m}$ in Al Burayrat area and $16 \mathrm{~m}$ near Wadi Al Bih main dam and decreased the average groundwater salinity from 2,122 milligrams per liter $(\mathrm{mg} / \mathrm{L})$ and 3,901 mg/L in Wadi Al Bih and Al Burayrat well fields, respectively, during the period 1991-1995, to 1,497 and 2,145 mg/L in Wadi Al Bih and Al Burayrat well fields, respectively, during the period 2010-2014. The decrease in aquifer's salinity due to the aquifer recovery was 30\% in Wadi Al Bih well field and 45\% in Al Burayrat well field.

The karstic nature and structural setting of Wadi Al Bih limestone aquifer increases secondary porosity and hydraulic conductivity (K ranges from 32.65 to $67.30 \mathrm{~m} / \mathrm{d}$ and averages $50 \mathrm{~m} / \mathrm{d}$ ) and enhances aquifer recharge. The temperature of the groundwater in Wadi $\mathrm{Al}$ Bih limestone aquifer varied between 32.8 and $43.3^{\circ} \mathrm{C}$, with averages of $36.1^{\circ} \mathrm{C}$ during winter and $36.3^{\circ} \mathrm{C}$ during summer. The average groundwater temperature decreases from 36.5 and $36.4^{\circ} \mathrm{C}$ during winter to 36.4 and $35.8^{\circ} \mathrm{C}$ during summer in Wadi $\mathrm{Al} \mathrm{Bih}$ and Al Burayrat well fields, respectively. The decrease of groundwater temperature in the aquifer is associated with decreasing salinity and indicates aquifer recharge from rains falling on the mountain peaks surrounding the basin.

Stable isotopes $\left({ }^{2} \mathrm{H}\right.$ and $\left.{ }^{18} \mathrm{O}\right)$ suggest water in Wadi $\mathrm{Al}$ Bih limestone aquifer is recharged at an average elevation of $1,050 \mathrm{~m}$. Tritium $\left({ }^{3} \mathrm{H}\right)$ data are consistent with a local source of precipitation and that the aquifer has a small residence time of a few years. Isotope and carbonate chemistry suggest that a significant amount of the groundwater in the Wadi Al Bih well field is recharged behind the dam. This is consistent with the observation that most of the groundwater samples collected in Wadi Al Bih limestone aquifer suggest recent recharge by exhibiting concentrations of a few tritium units.

Results of a groundwater flow model for Wadi Al Bih limestone aquifer reveal that the average annual groundwater production in the present $\left(4.5\right.$ million $\left.\mathrm{m}^{3}\right)$ is reasonably less than average annual aquifer recharge $\left(6.7\right.$ million $\left.\mathrm{m}^{3}\right)$, does not violate the aquifer's safe yield and ensures aquifer sustainability for years to come.
\end{abstract}

Keywords: Wadi Al Bih Limestone Aquifer, Safe Yield, Emirate of Ras Al Khaimah, United Arab Emirates.

* Corresponding author

E-mail: zrizk@ajman.ac.ae

(C) 2015 International Association for Sharing Knowledge and Sustainability

DOI: $10.5383 /$ swes.7.01.003 


\section{Introduction}

The demand for water is continually increasing to meet the needs of population growth, higher living standards, agricultural development, increasing per capita consumption, urban development and industrial expansion. In many areas of the world, groundwater withdrawal has resulted into aquifers' depletion and deterioration of groundwater quality (Fetter, 1994). Most the UAE aquifers are experiencing overexploitation and depletion problems. Most of the groundwater pumped from these aquifers comes from aquifers' storage, which is not compensated through recharge, due to the prevailing arid climate (Rizk et al., 1996). In fact, aquifers recharge in the UAE is limited to the mountain areas, including Wadi Al Bih limestone aquifer, and alluvial gravels at their foothills. The natural aquifers recharge in the UAE is estimated at 120 million $\mathrm{m}^{3}$ (Khalifa, 1995), while the groundwater pumping by the agricultural sector only is about one billion $\mathrm{m}^{3}$. Despite the achievements of the UAE in the field of water desalination, groundwater remains the main source of water used for irrigation. The number of wells allocated for irrigation increased from 13,818 wells in 1982 to 56,448 wells in 2000 , causing decline in groundwater levels, dryness of thousands of wells and increase of groundwater salinity.

The total annual fresh water consumption for different purposes in the UAE has reached 2.9 billion $\mathrm{m}^{3}$ in 2000, of which 2.2 billion $\mathrm{m}^{3}(82 \%)$ is groundwater and 700 million $\mathrm{m}^{3} \quad(18 \%)$ desalinated water. In 2011, while annual groundwater use slightly increased to about 2.3 billion $\mathrm{m}^{3}$, desalinated water increased about two and half folds to reach 1.7 billion $\mathrm{m}^{3}$. In spite of the decline in the contribution of groundwater to the domestic and urban sectors, the demand for groundwater is still increasing at a rate of 5\% per year According to estimates of the Ministry of Planning, the groundwater deficit increased from 585 million $\mathrm{m}^{3}$ in 1982 to 2,615 million $\mathrm{m}^{3}$ in 2005 , as a result of the steady increase in the agricultural area. A report for the ESCWA Organization (ESCWA, 2005) estimated the groundwater in the UAE during 2005 at 20 billion $\mathrm{m}^{3}$, in all aquifers. Other recent studies (MEW, 2010) estimated the reserves of usable groundwater quantities of 172 billion $\mathrm{m}^{3}$.

The major aquifers in the UAE are Wadi Al Bih limestone in the north (Fig. 1), ophiolite aquifer the east, eastern and western gravel aquifers surrounding the Northern Oman Mountains from the east and west and sand dune aquifer in the Western Region of the UAE. The main reserves of fresh groundwater are limited to Wadi $\mathrm{Al}$ Bih limestone aquifer in the northeast and the gravel aquifers in the eastern part of the UAE. The groundwater exploitation during the last four decades was 10 times the groundwater recharge, which has led to aquifers depletion at a rate of one billion $\mathrm{m}^{3}$ per year and water deficit of 4,669 million $\mathrm{m}^{3}$ in 2015. This deficit is predicted to double by the year 2025 (Table 1).

Wadi Al Bih limestone aquifer is the main source of water used for agricultural and domestic purposes in the Emirate of Ras Al Khaimah. For this reason, the aquifer was the subject of detailed studies on its hydrogeology, hydrogeochemistry and isotope hydrology (Electrowatt, 1981; Abu Al Enien, 1996; and Al Asam, 1998).
Studies also evaluated the suitability of the groundwater in the aquifer for different uses (Al Wahedi, 1997). Results of these investigations, in addition to results of ongoing research work, were used for answering the question raised in this study.

Table 1 Predicted Water Resources and Water Demand in the UAE for the Period 2015-2025 in Million M3 (World Bank, 2005)

\begin{tabular}{|l|l|l|l|}
\hline \multirow{2}{*}{ Water Resource } & \multicolumn{3}{|c|}{ Year } \\
\cline { 2 - 4 } & $\mathbf{2 0 1 5}$ & $\mathbf{2 0 2 0}$ & $\mathbf{2 0 2 5}$ \\
\hline Surface runoff & 150 & 150 & 150 \\
\hline Groundwater recharge & 125 & 125 & 125 \\
\hline Desalinated water & 2,342 & 3,688 & 5,806 \\
\hline Treated sewage water & 540 & 754 & 1,053 \\
\hline Total & 3157 & 4,717 & 7,134 \\
\hline \multirow{3}{*}{ Water Use } & \multicolumn{3}{|c|}{ Year } \\
\hline Domestic & $\mathbf{2 0 1 5}$ & $\mathbf{2 0 2 0}$ & $\mathbf{2 0 2 5}$ \\
\hline Industrial & 2,363 & 3,275 & 4,923 \\
\hline Agricultural & 597 & 715 & 895 \\
\hline Total & 4,866 & 6,207 & 8,561 \\
\hline Deficit & $\mathbf{7 , 8 2 6}$ & $\mathbf{1 0 , 1 9 7}$ & $\mathbf{1 4 , 3 8 0}$ \\
\hline & $-4,669$ & $-5,480$ & $-7,246$ \\
\hline
\end{tabular}

Materials and Methods

\section{Field Work}

During the period 1996-2015 a total of 193 groundwater samples were collected from Wadi Al Bih limestone aquifer and analyzed for major, minor and trace inorganic chemical constituents. The physical parameters of water such as temperature $\left({ }^{\circ} \mathrm{C}\right)$, electrical conductivity $(\mathrm{EC})$ in microsiemens per centimeters $(\mu \mathrm{S} / \mathrm{cm})$ and hydrogen ion concentration $(\mathrm{pH})$ were directly measured in the field because they change after sample collection (Hem 1985). Coordinates and depth to groundwater was measured in each sampled well for calculation of hydraulic heads in the aquifer and construction of potentiometric surface maps.

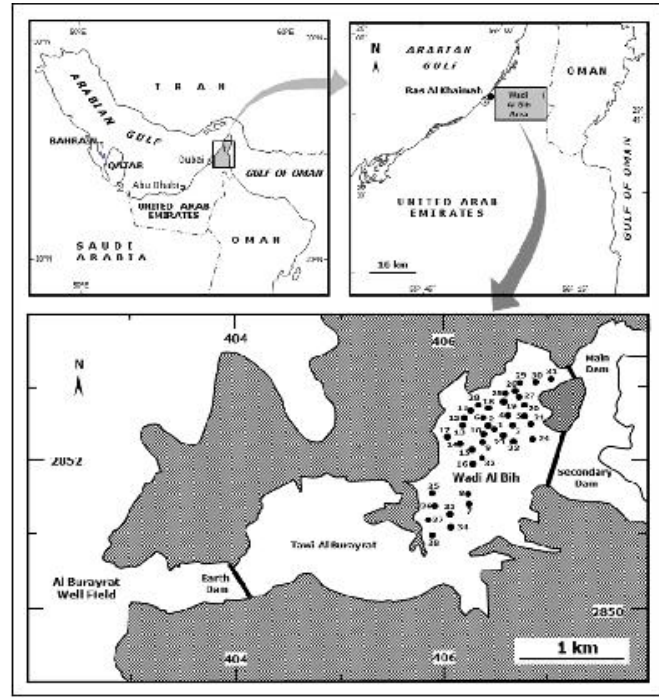

Fig. 1 Location of Ras Al Khaimah Area, Wadi Al Bih and Water Well Sampled for Investigation of Wadi Al Bih Limestone Aquifer 


\section{Laboratory Analyses}

The samples were analyzed in the Food and Environment Control Center, Abu Dhabi Municipality, Abu Dhabi, Desert and Marine Environment Research Center, UAE University, Al Ain and Food Control Laboratory at Ajman Municipality and Planning Department, Ajman. Standard analytical techniques described in Rainwater and Thatcher (1960), FAO (1970), Wood (1976), APHA (1995) and Skoog et al. (2004) were applied. Chemical analysis of major, minor and trace chemical constituents was performed using titration methods, ion chromatography (Weiss 1986), atomic absorption spectrophotometry (AAS) (Ediger 1973) and inductively coupled plasma-atomic emission spectrometry (ICP-AES) (Wolf and Grosser 1997).

For measurement of total dissolved solids (TDS), a $100 \mathrm{~mL}$ of well-mixed water sample was filtered through a standard glass fiber. The filtrate was evaporated to dryness in a weighed dish and dried to a constant weight at $180^{\circ} \mathrm{C}$. The increase in dish weight represented the TDS (APHA 1995).

For determination of alkalinity, soluble carbonate $\left(\mathrm{CO}_{3}{ }^{2-}\right)$ and bicarbonate $\left(\mathrm{HCO}_{3}{ }^{-}\right)$anions were measured by titration of 50 $\mathrm{mL}$ water sample against $0.02 \mathrm{~N} \mathrm{HCl}$ solution using phenolphthalein and methyl orange indicators (Skoog et al. 2004). Total hardness was measured by addition of $2 \mathrm{~mL}$ of the buffer solution $\mathrm{pH}-10$ and 3 to 4 drops of Erichrome Black $\mathrm{T}$ indicator to $10 \mathrm{ml}$ water sample, and titration with standard 0.01 M EDTA solution.

Ion chromatograph, model Dionex-2020i, was used for the analysis of the anions; chloride $\left(\mathrm{Cl}^{-}\right)$, nitrate $\left(\mathrm{NO}_{3}{ }^{-}\right)$and sulphate $\left(\mathrm{SO}_{4}{ }^{2-}\right)$. The Dionex-2020i ion chromatograph is a dual-channel, high-performance chromatographic system featuring two precision analytical pumps, a dual-channel advanced chromatography module with optional column heater and two conductivity detectors. The operating conditions were $10-40^{\circ} \mathrm{C}$ temperature range and 1,900 psi (129 atm.) maximum pressure. A calibration curve was prepared for each anion using aliquots anion concentrations higher than detection limits. The detection limits in $\mathrm{mg} / \mathrm{L}$ of $\mathrm{Cl}^{-}, \mathrm{NO}_{3}{ }^{-}$and $\mathrm{SO}_{4}{ }^{2-}$ were $0.03,0.13$ and 0.03 , respectively.

Prior to the determination of total metal concentrations by AAS or ICP-AES, each water sample was acidified with nitric acid ( $8 \mathrm{ml} / \mathrm{L}$ Analar grade), boiled for 4-5 minutes to ensure complete solubility of metal ions (Skoog et al. 2004), and then filtered. Filtrate was used for both AAS and ICPAES measurements. AAS was used for the determination of calcium $\left(\mathrm{Ca}^{2+}\right)$, magnesium $\left(\mathrm{Mg}^{2+}\right)$, sodium $\left(\mathrm{Na}^{+}\right)$and potassium $\left(\mathrm{K}^{+}\right)$ions by measuring their absorbance at the maximum wavelengths, against reagent blank (Ediger 1973) . Measurements were carried out using the Atomic Absorption Spectrometer (GBC 906), equipped with autosampler and background corrector. ICP-AES was used for determination of trace elements.

\section{Results and Discussion}

Sustainable aquifer is a renewable water-bearing formation receiving enough annual recharge to sustain its utilization without aquifer depletion or deterioration of groundwater quality.

Sustainable use of an aquifer takes into account its safe yield (Sy). Todd (1980) defined the safe yield of an aquifer system as the amount of water that can be withdrawn from it without producing an undesired effect. Aquifer usage is considered to be safe if the rate of groundwater withdrawal does not exceed the rate of natural recharge. Aquifer's safe yield also refers to the long-term natural replenishment rate of a particular aquifer system. If abstraction is kept to within this rate then there are unlikely to be long lasting issues (Alley at al. 1999). Safe yield is not a static figure however, but varies from season to season as rates of recharge and demand fluctuate (Davidson, 2012).

There are several evidences that Wadi Al Bih limestone aquifer is receiving present-day recharge, which makes it the most sustainable aquifer in the UAE. The evidences are derived from climate, geology, hydrogeology, hydrogeochemistry, isotope hydrology and numerical modeling.

\section{Climate}

The study area is arid $(155 \mathrm{~mm} / \mathrm{y})$ with hot summers that extend from May to October. The warmer summer months average daily highs of $44.4^{\circ} \mathrm{C}$, whereas the cold months daily highs average $13.2^{\circ} \mathrm{C}$. The mean annual average daily high temperature within the study area is $21.5^{\circ} \mathrm{C}$ (Al Wahedi, 1997). The mean annual pan evaporation from Wadi Al Bih catchment is $1,990 \mathrm{~mm}$, and the mean annual potential evapotranspiration is $3,320 \mathrm{~mm}$ (MAF, 1993a). The daily relative humidity ranges from 6 to $96 \%$ with the winter months being the most humid and May being the least humid (MAF, 1993a). Rainfall records obtained from six meteorological stations near Wadi Al Bih catchment indicate that the rainfall occurs mainly during February and March associated with the "Shamals" or northern winds where the Arabian Gulf provides the moisture. Occasionally, however, high-intensity rainfall may occur in late summer associated with the monsoons originating in the Indian Ocean. The steep slopes of watershed bounding Wadi Al Bih combined with modest vegetative cover and a bedrock surface of low permeability results in torrential flash floods. The estimated annual flood volume in Wadi Al Bih catchment area is 1.4 million $\mathrm{m}^{3}$ (MAF, 1993b). After construction of dams on Wadi Al Bih (Fig. 1), flooding of the lower reaches were significantly reduced (MAF, 1993b). Approximately 9\% (6.7 million $\mathrm{m}^{3}$ ) of the total annual rainfall (74 million $\mathrm{m}^{3}$ ) becomes groundwater in the catchment (Abu Al Enien, 1996; MAF, 1993a).

\section{Geology}

The study area lies within Ru'us Al Jibal Massif of the Oman Mountains, located on the southeastern edge of the Arabian Peninsula. Glennie et al. (1974) introduced the term Hajar Supergroup to describe the rock sequence, which he subdivided into three groups, from the base to top: Permian to Middle Triassic Ru'us Al Jibal Group, which includes Bih, Hagil and Ghail formations; Middle to Upper Triassic Elphinstone Group including Milaha sandstone Formation and Ghalilah dolomitic limestone Formation; and Early Jurassic to Lower Cretaceous Musandam Group. These three groups have a combined thickness of 3,500 $\mathrm{m}$ and form the outcrops and subcrops in the Wadi Al Bih drainage basin. The Hagil Formation is the main confined aquifer in the Wadi Bih basin consisting of $260 \mathrm{~m}$ of dolomitized, fine-grained, argillaceous limestone with occasional interbedded shale and characterized by karstic features and fractures (Hudson, 1960). The Bih Formation consists of approximately $200 \mathrm{~m}$ of medium-grained dolomite, with some fine-grained limestone and also contains karst features and fractures (Hudson and Chatton, 1959). The structural setting of the area affects its 
hydrogeology since most of the Wadi Al Bih tributaries are located along faults that allow surface water to move laterally or infiltrate into the subsurface. The Ru'us Al Jibal Massif forms a broad, block-faulted region of N-NE trends (Hunting, 1979a and 1979b). Post late Miocene through alluvial gravels (Fig. 2) cover the bedrock in the drainage channel of the lowlands of the wadi and average approximately $60 \mathrm{~m}$ in thickness. The gravels consist of clasts derived from outcrops in the highlands of the catchment (Al Asam, 1998).

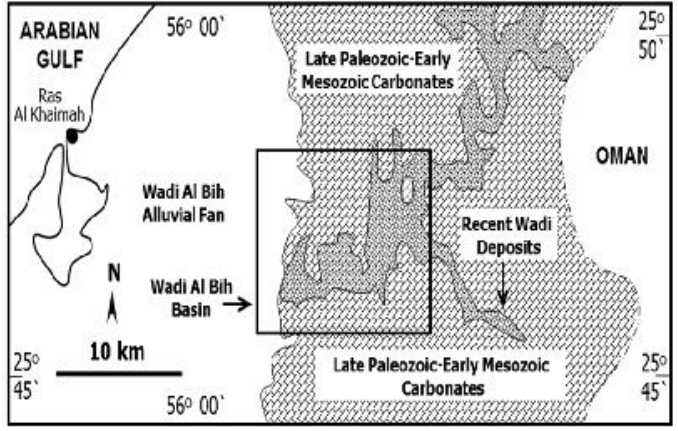

Fig. 2 Generalized Regional Geology that Includes Wadi Al Bih Study Area (Rizk et al. 2007)

\section{Hydrogeology}

The Wadi Al Bih fractured carbonate aquifer system is one in which rain falls on the topographically defined drainage basin and infiltrates directly into the exposed carbonate bedrock and overlying surficial alluvial gravels (Electrowatt Engineering, 1981). The average horizontal hydraulic conductivity of the fractured carbonate Hagil aquifer in Wadi Al Bih basin is approximately $33 \mathrm{~m} /$ day (Al Wahedi, 1997). The karstic nature of the aquifer, however, results in highly variable hydraulic conductivities. The potentiometric surface map constructed for the main Wadi Al Bih aquifer in April 1996 (Fig. 3) illustrates that the regional groundwater flow is from the east towards the Arabian Gulf in the west.

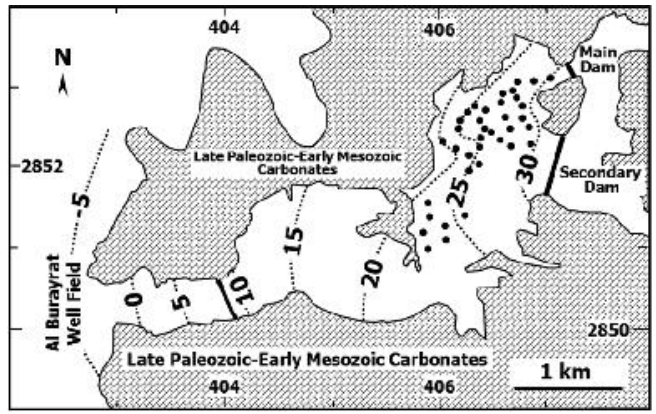

Fig. 3 Potentiometric Surface Map of Wadi Al Bih Limestone Aquifer, in Meters Relative to Sea Level, and Wadi Al Bih Dams (Rizk et al. 2007)

The potentiometric surface ranges from $30 \mathrm{~m}$ above sea level in the vicinity of the main and secondary dams to $5 \mathrm{~m}$ below sea level in Al Burayrat well field area nearer the coast (Fig. $3)$.

The aquifer is recharged through Wadi Al Bih dry drainage basin with a total catchment area of $475 \mathrm{~km}^{2}$. The maximum topographic elevation in the basin is $2,090 \mathrm{~m}$ and its average height above sea level is $1,050 \mathrm{~m}$ (Rizk et al., 2007).

Abu Enein (1996) estimated that $\approx 9 \%$ of rain falling on Wadi Al Bih drainage basin recharges the limestone aquifer, while $85 \%$ of rainfall is lost through evapotranspiration and the remaining $6 \%$ reaches the Arabian Gulf in the west. After construction of Wadi Al Bih dam in 1982, the percentage of groundwater recharge from rainfall has increased to $13 \%$, while the amount of annual recharge for the limestone aquifer in Wadi Al Bih basin was 9.57 million $\mathrm{m}^{3}$. The hydraulic conductivity of Wadi $\mathrm{Al}$ Bih limestone aquifers varies between 33 and 67 meters per day, with an average of 50 meters per day.

Construction of Wadi Al Bih dam caused 15 meters rise in groundwater level in the eastern region of Wadi $\mathrm{Al}$ Bih basin (Al Asam, 1998). The aquifer's transmissivity varies between 1,324 and $2,729 \mathrm{~m}^{2} /$ day, while storage coefficient (Sc) ranged from $8.26 \times 10^{-5}$ to $1.53 \times 10^{-3}$, indicating that the aquifer is confined.

\section{Hydrogeochemistry}

The total dissolved solids (TDS) concentration of Wadi Al Bih well field vary between 481 and 6,908 milligrams per liter $(\mathrm{mg} / \mathrm{L})$, with an annual average of $2,032 \mathrm{mg} / \mathrm{L}$. Chloride $\left(\mathrm{Cl}^{-}\right)$is the dominant anion ranging in concentration from 110 to $4,710 \mathrm{mg} / \mathrm{L}$ with an annual average of $1,206 \mathrm{mg} / \mathrm{L}$. Sodium $\left(\mathrm{Na}^{+}\right)$is the dominant cation ranging from 88 to $1,360 \mathrm{mg} / \mathrm{L}$ with an annual average concentration of $405 \mathrm{mg} / \mathrm{L}$. Both major ions exhibited large variability in the same well between April and September. The $\mathrm{pH}$ value varies between 7.1 and 7.7, with an average of 7.4 in April and 7.5 in September. The temperature of the groundwater samples collected from Wadi Al Bih aquifer varied between $32.8^{\circ} \mathrm{C}$ and $43.3^{\circ} \mathrm{C}$, with averages of $36.1{ }^{\circ} \mathrm{C}$ during April and $36.3^{\circ} \mathrm{C}$ during September. The groundwater temperature decreased from 36.5 and $36.4^{\circ} \mathrm{C}$ during winter to 36.4 and $35.8^{\circ} \mathrm{C}$ during summer in Wadi $\mathrm{Al}$ Bih and $\mathrm{Al}$ Burayrat well fields, respectively. The spatial and temporal distribution of temperature is given in Figure 4.

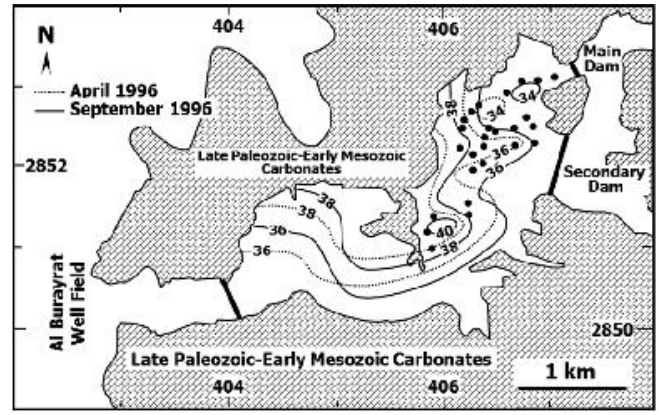

Fig. 4 Temperature $\left({ }^{\circ} \mathrm{C}\right)$ Contours for Groundwater in Wadi Al Bih Limestone Aquifer (Rizk et al. 2007)

During September, the average TDS and major ions, except bicarbonate $\left(\mathrm{HCO}_{3}{ }^{-}\right)$, were significantly greater relative to the April average.

The TDS of groundwater in Wadi Al Bih varies between 593 and $7,007 \mathrm{mg} / \mathrm{L}$, and averages of $2,122 \mathrm{mg} / \mathrm{L}$, and between 979 and $6,642 \mathrm{mg} / \mathrm{L}$, with an average of $3,901 \mathrm{mg} / \mathrm{L}$ in $\mathrm{Al}$ Burayrat. The spatial and temporal distribution of TDS is given in Figure 5. The decrease of groundwater temperature in the limestone aquifer within Wadi $\mathrm{Al}$ Bih limestone aquifer 
was associated with decreasing TDS (Figures 4 and 5). This indicates that the groundwater is receiving recharge from rains falling on the mountain peaks surrounding the basin. The recharge water moving through fissures and fractures is certainly lower in temperature and salinity than groundwater in the aquifer.

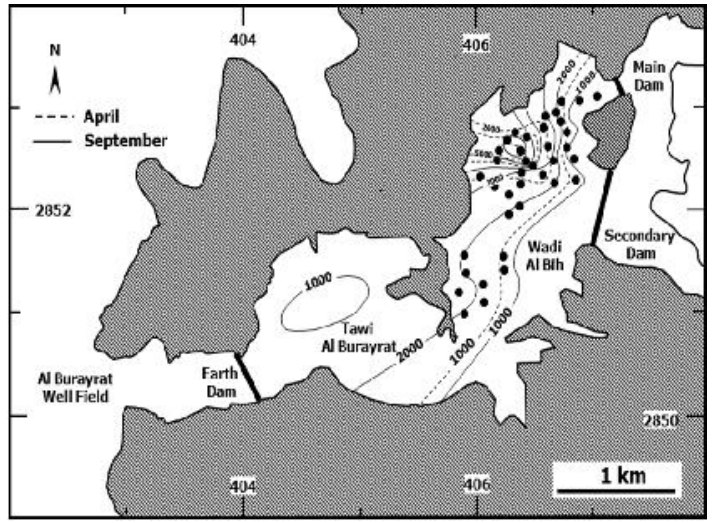

Fig. 5 TDS Contours for Groundwater of Wadi Al Bih Limestone Aquifer, in mg/L (Rizk et al. 2007)

The regional TDS contour map (Fig. 5) shows a general increase in Wadi Al Bih limestone aquifer from east to west, in the direction of groundwater flow.

\section{Isotope Hydrology}

Most of the water samples collected in Wadi Al Bih limestone aquifer exhibit radioactive tritium $\left({ }^{3} \mathrm{H}\right)$ introduced into the hydrosphere by thermonuclear testing in the atmosphere in the early 1960's (Gonfiantini 1996; Fig. 6).

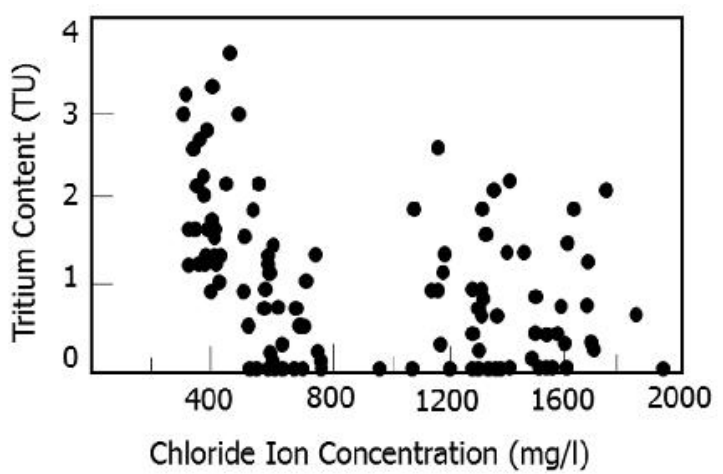

Fig. 6 Graph Showing Tritium $\left({ }^{3} H\right)$ In Tritium Units (TU), Versus Chloride $\left(\mathrm{Cl}^{-}\right)$Concentration, In $\mathrm{Mg} / \mathrm{L}$, in Groundwater from Wadi Al Bih Limestone Aquifer (Rizk et al. 2007)

As the half-life of tritium is 12.5 years, its presence suggests relatively recent recharge and short residence time in the aquifer consistent with the fractured karstic nature of the aquifer system. Groundwater and rainwater samples collected in the northern Emirates by the UAE Ministry of Electricity and Water during the period 1984-1992 were analyzed for ${ }^{2} \mathrm{H}$ and $\delta^{18} \mathrm{O}$, expressed as permil (\%), by the IAEA (International Atomic Energy Agency) in Vienna, Austria. Global Meteoric Water Line (GMWL) has an expression of $\delta^{2} \mathrm{H}=8 \delta^{18} \mathrm{O}+10$ (Fig. 7). Local Meteoric Water Line (LMWL) for the Wadi Al Bih area is best given by the expression $\delta^{2} \mathrm{H}=4.3 \delta^{18} \mathrm{O}+8.9$ (Fig. 7). The groundwater samples are clustered in a narrow range of values expressed as $\delta^{2} \mathrm{H}=2.8 \delta^{18} \mathrm{O}-5.0$ (Fig. 7). These data suggest that there has been significant evaporation prior to recharge as the slope of the $\delta^{2} \mathrm{H} / \delta^{18} \mathrm{O}$ relation (2.8) is less than the LMWL (4.3) and excess deuterium function declines from +8.9 to -5.0 .

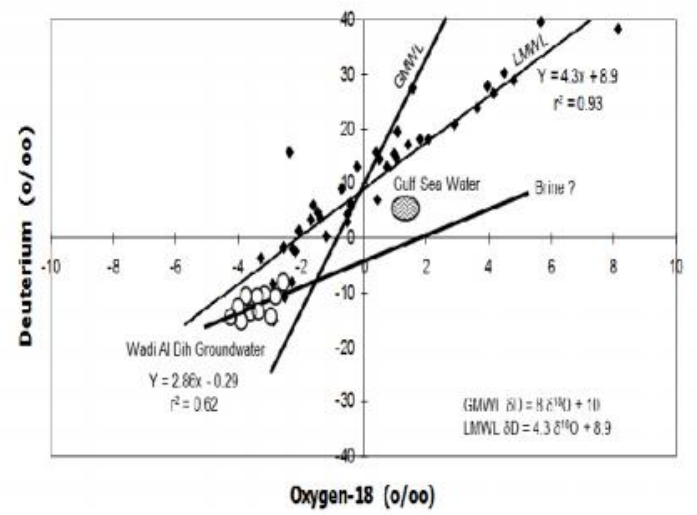

Fig. 7 Graph Showing Stable Isotopes of Hydrogen and Oxygen in Water, in Delta Notation, for Global Meteoric Water Line (GMWL), Local Meteoric Water Line (LMWL), Groundwater from Wadi Al Bih Limestone Aquifer and the Arabian Gulf (Rizk et al. 2007)

The isotopically depleted values of groundwater, with respect to local precipitation (Fig. 8), suggest the recharge zone is at a higher elevation than the precipitation collection sites on the wadi floor and near the Arabian Gulf coast (Akiti et al., 1992; Gonfiantini, 1992; Yurtsever, 1992 and 1996; Wagner, 1997). An estimate of the average elevation of recharge is made using a mean $\delta^{18} \mathrm{O}=-3 \%$ for groundwater, a mean $\delta^{18} \mathrm{O}=$ $1.1 \%$ for measured rainfall near the global meteoric water line (GMWL) and the arid zone adiabatic change in $\delta^{18} \mathrm{O}$ of $0.2 \%$ per a $100 \mathrm{~m}$ increase in elevation (Eriksson, 1983). The average elevation of recharge calculated in this way would be $1,050 \mathrm{~m}$. The maximum elevation of the surrounding peaks in the Ru'us Al Jibal Mountains is 2,090 m, thus, the estimate of $1,050 \mathrm{~m}$ consistent with water from local precipitation falling on the basin. From tritium and stable water isotopes, it is clear that the water is locally derived precipitation (Fig. 6). The study of isotopes and carbonate chemistry indicate that the main portion groundwater produced by the FEWA well field comes from Wadi Al Bih recharge dam (Fig. 6).

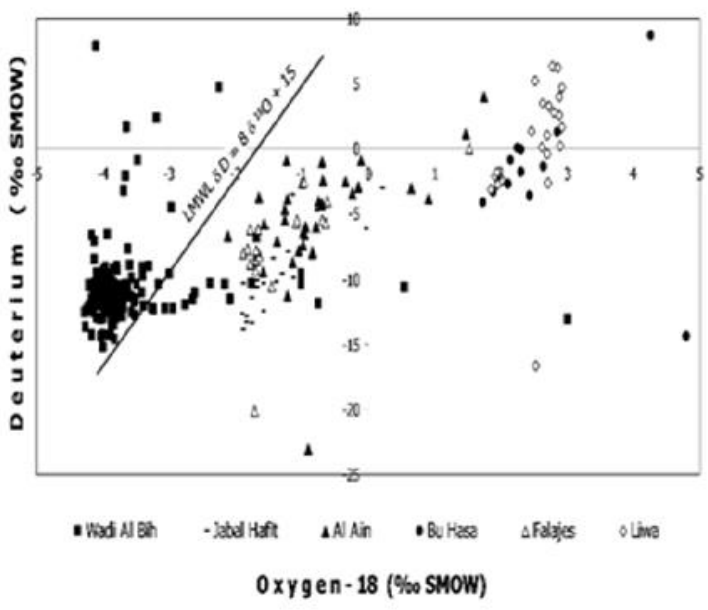

Fig. 8 Stable Isotopes of Hydrogen $\left({ }^{2} \mathrm{H} \%\right)$ and Oxygen $\left({ }^{18} \mathrm{O} \%\right)$ in Rain Water, Falajs Water, Wadi Al Bih Limestone Aquifer, Jabal Hafit Limestone Aquifer, Western Gravel Aquifer in Al 
Ain and the Liwa Quaternary Aquifer in the Western Region of the UAE (Rizk and Alsharhan, 1999)

\section{Recharge-Discharge Relationship}

The study area is recharged from a catchment of $475 \mathrm{~km}^{2}$ area, with average elevation of $1,050 \mathrm{~m}$ above sea level. Figure 9 illustrates the change in groundwater level in observation wells behind UAE recharge dams, including Wadi Al Bih dam. It also shows that that amount of water stored in the aquifer is highly dependent on rainfall.

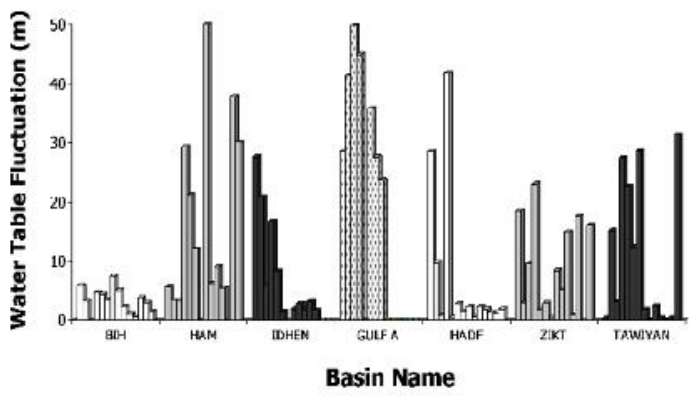

Fig. 9 Fluctuations of Groundwater Levels, Measured in Observation Wells behind Main Recharge Dams in the UAE for the Period 1992-2005 (Rizk and Alsharhan, 2008)

The groundwater production from Wadi Al Bih will field during the periods 1991-1995 and 2010-2014 is illustrated in Table 2. Fortunately, the production dropped about 9 million $\mathrm{m}^{3}$ per year during the period 1991-1995 to about 4.5 million $\mathrm{m}^{3}$ per year during the period 2010-2014. The difference in production rates between the two periods was compensated for by water produced by the newly constructed desalination plants such as Al Burayrat, Al Nakheel and Ghalilah.

Table 2 Groundwater Production from Wadi Al Bih Well Fields during the Periods 1991-1995 and 2010-2014 Based on Data from the Ministry of Environment and Water

\begin{tabular}{|l|l|l|l|}
\hline Year & $\mathbf{m}^{\mathbf{3}}$ & Year & $\mathbf{m}^{\mathbf{3}}$ \\
\hline 1991 & $8,236,479$ & 2010 & $3,986,328.67$ \\
\hline 1992 & $8,139,502$ & 2011 & $4,338,638.13$ \\
\hline 1993 & $8,813,592$ & 2012 & $5,141,370.47$ \\
\hline 1994 & $10,669,475$ & 2013 & $4,408,023.35$ \\
\hline 1995 & $9,727,992$ & 2014 & $4,476,923.20$ \\
\hline Average & $\mathbf{9 , 1 1 7 , 4 0 8}$ & Average & $\mathbf{4 , 4 7 0 , 2 5 7}$ \\
\hline
\end{tabular}

The reduction of water from the aquifer has increased groundwater storage, rose of hydraulic heads and decreased the average groundwater salinity by $30 \%$ in Wadi Al Bih well field and $45 \%$ in Al Burayrat well field.

\section{Numerical Modeling}

The results of a numerical model for Wadi Al Bih limestone aquifer, using Visual Modflow, revealed that the construction of Wadi Al Bih dam has increased groundwater level by $1 \mathrm{~m}$ in Al Burayrat well field and $16 \mathrm{~m}$ near Wadi Al Bih main dam. The model also estimated the average annual recharge and discharge for the aquifer (Table 3; Al Wahedi (1997).

Table 3 Model Calculated Recharge and Discharge for Wadi Al Bih Limestone Aquifer during the Periods 1991-1995 (Al Wahedi, 1997)

\begin{tabular}{|l|l|l|}
\hline Year & Recharge $\left.\mathbf{( m}^{\mathbf{3}}\right)$ & Discharge $\mathbf{( m}^{\mathbf{3}} \mathbf{)}$ \\
\hline 1991 & $5,610,000$ & $9,781,024$ \\
\hline 1992 & $12,280,000$ & $9,659,429$ \\
\hline 1993 & $13,850,000$ & $11,420,351$ \\
\hline 1994 & $13,400,000$ & $13,124,364$ \\
\hline 1995 & $9,560,000$ & $12,177,727$ \\
\hline Average & $\mathbf{9 , 5 7 0 , 0 0 0}$ & $\mathbf{1 1 , 2 3 2 , 5 7 9}$ \\
\hline
\end{tabular}

\section{Conclusions}

Results show that Wadi Al Bih basin receives an average annual rainfall of $155 \mathrm{~mm}$, above the UAE average of 119 $\mathrm{mm}$. Annual rainfall in excess of $400 \mathrm{~mm}$ is common in the Emirate of Ras Al Khaimah. The percentage of aquifer recharge from the total annual rainfall $\left(74\right.$ million $\left.\mathrm{m}^{3}\right)$ was $\approx 9 \%\left(6.7\right.$ million $\left.\mathrm{m}^{3}\right)$, increased to $13 \%\left(17.6\right.$ million $\left.\mathrm{m}^{3}\right)$ after construction of Wadi Al Bih dam in 1982. In the meantime, the reduction of average annual groundwater production from Wadi Al Bih limestone aquifer decreased from 9 million $\mathrm{m}^{3}$ during the period 1991-1995 to 4.5 million $\mathrm{m}^{3}$ during the period 2010-2014. The decrease in groundwater pumping from the aquifer along with the construction of $\mathrm{Al}$ Burayrat, Al Humraniah, Rafaq, Ghalilah and Al Nakheel desalination plants, has increased groundwater storage, rose of hydraulic heads by $1 \mathrm{~m}$ in Al Burayrat area and $16 \mathrm{~m}$ near Wadi Al Bih main dam, and decreased the average groundwater salinity by $30 \%$ in Wadi Al Bih well field and $40 \%$ in Al Burayrat well field (Table 4).

The rocks forming the aquifer are stratified, solid, dense and impermeable, but characterized by a network of extensive, internal karstification mass, which increases secondary porosity and hydraulic conductivity ( $\mathrm{K}$ varies between 32.65 and $67.30 \mathrm{~m} / \mathrm{d}$ and averages $50 \mathrm{~m} / \mathrm{d}$ ). The structural setting of the study area affects aquifer recharge since most of the Wadi Al Bih tributaries are located along faults that allow surface water to move laterally or infiltrate into the subsurface. The temperature of the groundwater samples collected from Wadi $\mathrm{Al}$ Bih aquifer varied between 32.8 and $43.3^{\circ} \mathrm{C}$, with averages of $36.1^{\circ} \mathrm{C}$ during winter and $36.3^{\circ} \mathrm{C}$ during summer. The average groundwater temperature decreases from 36.5 and $36.4^{\circ} \mathrm{C}$ during winter to 36.4 and $35.8^{\circ} \mathrm{C}$ during summer in Wadi Al Bih and Al Burayrat well fields, respectively. The decrease of groundwater temperature with decreasing TDS indicates that the aquifer is receiving recharge from rains falling on the mountain peaks surrounding the Wadi Al Bih basin.

Stable isotopes $\left({ }^{2} \mathrm{H}\right.$ and $\left.{ }^{18} \mathrm{O}\right)$ suggest water in Wadi $\mathrm{Al}$ Bih limestone aquifer is recharged at an average elevation of $1,050 \mathrm{~m}$. Tritium $\left({ }^{3} \mathrm{H}\right)$ data are consistent with a local source of precipitation and that the aquifer has a small residence time of a few years. Isotope and carbonate chemistry suggest that a significant amount of the groundwater in the Wadi Al Bih well field is recharged behind the dam. This is consistent with the concentration tritium in the aquifer.

Wadi Al Bih limestone aquifer in the Emirate of Ras Al Khaimah represents an excellent model for proper 
management of groundwater resources in the UAE, taking into account the safe yield of each aquifer.

\section{References}

[1] Al Wahedi, A.A., 1997, Assessment of Environmental Impact of Re-Injecting Oil-Field Water in the Miocene Clastic Sediments on the Shallow Aquifer at Bu Hasa Oil Field, United Arab Emirates: Unpublished M. Sc. Thesis, UAE University, Al Ain, UAE, $121 \mathrm{p}$.

[2] Al Asam, M.S., 1998, Application of Geophysical and Geochemical Techniques for Assessment of Groundwater Recharge from Wadi Al Bih Dams, Ras Al Khaimah, United Arab Emirates: Unpublished M. Sc. Thesis, UAE University, Al Ain, UAE, 108 p.

[3] Alley, W.M., Reilly, T.E. and Franke, O.L., 1999 , Sustainability of groundwater resources: U.S. Geological Survey Circular 1186, Denver, Colorado, USA, 79 p.

[4] Abu Al Enien, H., 1996, Wadi Al Bih alluvial fan water resources: Al Kuwait University, Geography Department, Publ. No. 198, 78 p.

[5] Akiti, T.T, Gonfiantini, R., and Mutawa, A., 1992 Aspects of isotope hydrology of the United Arab Emirates: Ministry of Electricity and Water internal report, $50 \mathrm{p}$.

[6] APHA, 1995, Standard methods for examination of water and waste water: 19th edition. APHA $2540 \mathrm{C}$

[7] Davidson, P., 2012, Aquifer Safe Yield Review 2012 MDC Technical Report No: 12-009, Marlborough District Council, Blenheim, New Zealand, $50 \mathrm{p}$.

[8] Ediger, R.D., 1973, A review of water analysis by atomic absorption: Atomic Absorption Newsletter 12:151

[9] Electrowatt Engineering, 1981, Wadi Al Bih dam and groundwater recharge facilities: Ministry of Agriculture and Fisheries, v. 1,67 p

[10] Eriksson, E., 1983, Stable isotopes and tritium in precipitation: Guidebook on nuclear techniques in hydrology, Technical Report Series No. 91, IAEA, pp. 19-33.

[11] ESCWA, 2005, Development of frameworks to implement national strategies of integrated water resources management in the ESCWA countries: United Nations, New York, 94 p. (in Arabic).

[12] FAO, 1970, Physical and chemical methods of soil and water analysis: Soil Bull. No. 10, p. 236-238.

[13] Fetter, C. W., 1994, Applied Hydrology, 3rd Edition Macmillan Co. New York, 691 p.

[14] Glennie, K.W., Boeuf, M.G.A., Hughe Clark, M.W., Moody-Stuart, W.F.H., Piller, W.F.H., and Reinhardt, P.M., 1974, Geology of the Oman Mountains, Parts I, II, III. Verh. Kon. Nederlands Geol. Mijn. Gen. Transactions, Geol. Servey, v. 31, 423 p

[15] Gonfiantini, R., 1992, Investigation of ground water resources of the United Arab Emirates by using isotope techniques: IAEA Report (UAE/8/92), Vienna, Austria, $34 \mathrm{p}$.

[16] Gonfiantini, R., 1996, On the isotope composition of precipitation. In Jean Charles Fontes (1936-1994) Un souvenir, Proceedings International Symposium, December 1995, European Geologists, v2; p.5-8.

[17] Hem, J.D., 1985, Study and interpretation of chemical characteristics of natural water: U. S. Geological Survey Water Supply Paper no. 1473, 363 p.

[18] Hudson, R. G. S., 1960, The Permian and Triassic of the Oman Peninsula Arabia. The Geological Magazine, v. XCVII, no. 4, pp. 299-308.

[19] Hudson, R. G. S., and Chatton, M., 1959, The Musandam limestone (Jurassic to Lower Cretaceous) of Oman,
Arabia: Museum National D'histoire Naturelle, Paris, v. VII, pp. 69-91.

[20] Hunting 1979a, Geological map of the United Arab Emirates: Ministry of Petroleum and Mineral Resources, U. A. E.

[21] Hunting, 1979b, Report on a mineral survey of the U. A. E. 1977-1979: Ministry of Petroleum and Mineral Resources, v.1, pp. 1-34

[22] Khalifa, A.A., 1995, Surface water and Groundwater resources in UAE: Culture and Science Society, Meeting on Water Balance inn UAE, Dubai, 12 p.

[23] MAF (Ministry of Agriculture and Fisheries), 1993a, Climatological data: Department of soil and water, v. 3, $443 \mathrm{pp}$.

[24] MAF (Ministry of Agriculture and Fisheries), 1993b Hydrology, v. 3, 1980-1991: Department of Soil and Water, MAF, U.A.E., 294 p.

[25] MEW (Ministry of Environment and Water), 2010, Water Conservation Strategy: Ministry of Environment and Water, $212 \mathrm{p}$.

[26] Rainwater, F.A., and Thatcher, L.L., 1960, Methods for collection and analysis of water samples: U. S. Geological Survey Water Supply Paper no. 1454, Washington, p. 1-301.

[27] Rizk, Z.S. and Alsharhan, A.S., and Shindo S., 1996, Evaluation of groundwater resources of the United Arab Emirates: The Proceedings of the 3rd Gulf Water Conference, Oman, pp. 93-105.

[28] Rizk, Z.S., and Alsharhan, A.S., 1999, Application of natural isotopes for hydrogeologic investigations in United Arab Emirates: Proceedings of the Fourth Gulf Water conference, Manama, Bahrain, pp. 197-228.

[29] Rizk, Z.R., Alsharhan, A.S., and Wood, W.W., 2007, Source of dissolved solids and water in Wadi Al Bih aquifer, Ras Al Khaimah Emirate, United Arab Emirates: Hydrogeology Journal, 15: 1553-1563.

[30] Rizk, Z.S., and Alsharhan, A.S., 2008, Water Resources in the United Arab Emirates: Ithraa Publishing and Distribution, Amman, Jordan, 624 p. (in Arabic).

[31] Skoog, D.A., West, D.M. Holler, F. J. and Crouch, S.R., 2004, Fundamental Analytical Chemistry, 8th Edition: Thomson Brooks/Cole, USA, $870 \mathrm{p}$.

[32] Todd, D. K., 1980, Groundwater hydrology: John Wiley and Sons, New York (second edition), $535 \mathrm{p}$.

[33] Wagner, Wolfgang, 1997, Renewable groundwater resources in dry areas of the ESCWA region - origin and isotopic characteristics: A Regional Training Workshop on Geochemical Modeling Methods for Geochemistry Evaluation and Water Pollution Studies: UAE University, $11 \mathrm{p}$.

[34] Weiss, J., 1986, Handbook of ion chromatography: E.L. Johnson, ed. Dionex Corp., Sunnyvale, California, USA.

[35] Wolf, R.E. and Grosser, Z.A., 1997, Overview and comparison of ICP-MS methods for environmental analyses: Atomic Spectroscopy. 18(5), 145-151

[36] Wood, W. W., 1976, Guidelines for collection and field analysis of ground-water samples for selected unstable constituents: Techniques of Water Resources Investigations, U. S. Geological Survey, Book 1, Chapter D2, U. S. Government Printing Office, $24 \mathrm{p}$.

[37] World Bank, 2005, Evaluation of water sector in the GCC countries: Arab Gulf Program for United Nations Development Organizations, 113 p. (in Arabic).

[38] Yurtsever, 1992, Preliminary evaluation of isotope results from reconnaissance samples collected in Kuwait: IAEA Technical Cooperation project, Isotope Hydrology of the Middle East, $12 \mathrm{p}$.

[39] Yurtsever, 1996, Isotope methods in water resources management and examples of applications in the Gulf region: Water Management Conference, Abu Dhabi, 15 p. 
Rizk / Int. J. of Sustainable Water \& Environmental Systems, 7 (2015) 21-28

Table 4: Comparison between Al Bih and Burayrat Groundwater Chemistry in 1996 and 2014 with World Health Organization (WHO; 1984) and Gulf Cooperation Council (GCC; 1993) Standards for Drinking Water.

\begin{tabular}{|c|c|c|c|c|c|c|c|c|c|c|c|c|c|c|}
\hline \multirow{3}{*}{ Parameter } & \multicolumn{6}{|c|}{ Year 1996} & \multicolumn{6}{|c|}{ Year 2014} & \multirow{3}{*}{$\begin{array}{c}\text { WHO } \\
\text { Guideline }\end{array}$} & \multirow{3}{*}{$\begin{array}{c}\text { GCC } \\
\text { Max. level }\end{array}$} \\
\hline & \multicolumn{3}{|c|}{ Wadi Al Bih } & \multicolumn{3}{|c|}{ Al Burayrat } & \multicolumn{3}{|c|}{ Wadi Al Bih } & \multicolumn{3}{|c|}{ Al Burayrat } & & \\
\hline & Max. & Min. & Mean & Max. & Min. & Mean & Max. & Min. & Mean & Max. & Min. & Mean & & \\
\hline $\mathrm{pH}$ & 7.8 & 7.1 & 7.4 & 7.9 & 7.3 & 7.5 & 7.3 & 6.0 & 6.9 & 7.1 & 6.8 & 6.9 & $6.5-8.5$ & $6.5-8.5$ \\
\hline Temperature & 43.3 & 32.8 & 36.4 & 36.9 & 35.2 & 36.2 & 37.6 & 30.8 & 35.5 & 36.1 & 35.2 & 35.6 & & \\
\hline TDS & 7,007 & 593 & 2,122 & 6,642 & 979 & 3,901 & 3,276 & 237 & 1,497 & 2,890 & 1,648 & 2,145 & 1,000 & $100-1,000$ \\
\hline $\mathrm{EC}$ & 9,330 & 940 & 3,166 & 9,170 & 1,567 & 6,073 & 4,680 & 365 & 2,274 & 4,006 & 2,646 & 3,159 & 1,400 & $160-1,600$ \\
\hline Total Hardness & 1,272 & 189 & 502 & 1,277 & 264 & 1,008 & 1,200 & 230 & 488 & 680 & 480 & 568 & 500 & 500 \\
\hline $\mathrm{Ca}^{2+}$ & 277 & 37 & 96 & 281 & 30 & 135 & 220 & 36 & 103 & 192 & 120 & 159 & $75-200$ & 200 \\
\hline $\mathrm{Mg}^{2+}$ & 108 & 13 & 39 & 141 & 11 & 77 & 244 & 2.4 & 57 & 59 & 17 & 40 & $30-150$ & $30-150$ \\
\hline $\mathrm{Na}^{+}$ & 1,362 & 88 & 400 & 1,276 & 110 & 674 & 726 & 19 & 327 & 692 & 330 & 524 & 200 & 200 \\
\hline $\mathrm{K}^{+}$ & 87 & 10 & 30 & 111 & 9 & 53 & 65 & 5 & 21 & 38 & 21 & 25 & & \\
\hline $\mathrm{CO}_{3}{ }^{2-}$ & 19 & 3.6 & 10.9 & 26.3 & 7.2 & 16.3 & N. M. & N. M. & N. M. & N. M. & N. M. & N. M. & & \\
\hline $\mathrm{HCO}_{3}{ }^{-}$ & 204 & 131 & 160 & 188 & 153 & 172 & 207 & 56 & 1556 & 185 & 159 & 171 & & \\
\hline $\mathrm{Cl}^{-}$ & 4,712 & 112 & 1,201 & 4,200 & 482 & 2,441 & 1,849 & 23 & 725 & 1,550 & 830 & 1,092 & 250 & 250 \\
\hline $\mathrm{NO}_{3}{ }^{-}$ & 9 & 0.0 & 5 & 8 & 2 & 5 & 14 & 5 & 8 & 7 & 6 & 6 & 10 & 10 \\
\hline $\mathrm{SO}_{4}{ }^{2-}$ & 270 & 74 & 162 & 475 & 115 & 309 & 200 & 21 & 101 & 210 & 80 & 114 & $200-400$ & 400 \\
\hline
\end{tabular}

Temperature (T) is measured in degree Celsius $\left({ }^{\circ} \mathrm{C}\right.$ ). Total dissolved solids (TDS), total hardness (TH) and concentrations of major ions are expressed in milligrams per liter (mg/L). Electrical conductivity (EC) is measured in microsiemens per centimeter $(\mathrm{S} / \mathrm{cm})$. Means are calculated for the total numberof the samples and N.M. is a parameter not measured in 2014 samples. 